*УДК 332.02

Вахновська Н.А., к.е.н., доцент

Зінюк Л.О.

Луцький національний технічний університет

\title{
ДО ПИТАННЯ РОЗВИТКУ СТРАХОВОГО РИНКУ УКРАЇНИ
}

У публікації підлягають розгляду питання щодо особливостей функціонування страхового ринку в Україні, обгрунтовано основні чинники впливу на його розвиток. Визначено основні проблеми та шляхи їх подолання в контексті реформування страхового ринку.

Ключові слова: страховий ринок, розвиток страхового ринку, страхові премії, страхові виплати.

\section{Vakhnovska N., Zinyuk L. ON THE DEVELOPMENT OF THE INSURANCE MARKET OF UKRAINE}

The insurance sector plays an important role in the socio-economic development of the country, effectively managing the risks in the country and protecting the interests of insurers.

As the economy develops, the Ukrainian insurance market is changing rapidly. However, changing economic conditions create new problems that hinder the effectiveness of the insurance market, which is the key to stability and prosperity in society. That is why it is necessary to identify the negative factors influencing the insurance market and search for new promising directions of development.

The state's interest in insurance development is conditioned by the adoption and approval of insurance market development programs. The article gives a list of the tasks set and fulfilled by the government under these development programs in Ukraine.

The formation and development of the insurance market occurred in the absence of an effective regulatory framework, in the absence of effective state oversight of insurers and in times of economic crisis. Therefore, it is impossible to say with certainty at what stage of development the insurance market of Ukraine is located, because many problems in insurance activity are needed to solve.

The negative factors do not allow the insurance market to fully develop, forcing foreign investors to look for other, more attractive options for investing in the insurance industry. In order to overcome the problems and reform the insurance market, it is necessary to: stimulate insurers to obtain international financial reliability ratings; to define a single and effective strategy for the development of the Ukrainian insurance market; to introduce world standards of insurance business; strengthen the control of

* Вахновська Н.А., Зінюк Л.О. 
"Економічні науки". - Серія "Облік і фінанси". - Випуск 16 (61). - 2019.

insurers by public authorities to ensure solvency and financial sustainability; to create a qualitative system of training highly qualified personnel for the insurance industry; strengthen the work on the creation and implementation of additional regulatory acts.

Key words: insurance market, insurance market development, insurance premiums, insurance payments.

Вахновская Н.А., Зинюк Л.А.

\section{К ВОПРОСУ РАЗВИТИЯ СТРАХОВОГО РЫНКА УКРАИНЫ}

В публикации подлежат рассмотрению вопросы об особенностях функционирования страхового рынка в Украине, обоснованы основные факторы влияния на его развитие. Определены основные проблемы и пути их преодоления в контексте реформирования страхового рынка.

Ключевые слова: страховой рынок, развитие страхового рынка, страховые премии, страховые выплаты.

Постановка проблеми у загальному вигляді та її зв'язок 3 важливими науковими та практичними завданнями. На сьогодні страховий сектор відіграє важливу роль у соціальноекономічному розвитку держави, ефективно управляючи ризиками в країні та захищаючи інтереси страхувальників. Ефективно функціонуючий страховий ринок надає можливість захисту бізнесу від непередбачуваних ризиків, а також створює страховий захист населення від наслідків несприятливих подій. Крім того, за рахунок мобілізації тимчасово вільних коштів страхувальників, страхова сфера забезпечує попит держави у інвестиційних ресурсах, які здатні стимулювати економіку країни.

3 розвитком економіки страховий ринок України стрімко змінюється. Проте зміна економічних умов функціонування породжує нові проблеми, які гальмують дієвість страхового ринку, яка $є$ запорукою стабільності та добробуту у суспільстві. Саме тому необхідним є визначення негативних факторів впливу на страховий ринок та пошук нових перспективних напрямів розвитку.

Аналіз останніх досліджень, у яких започатковано вирішення проблеми. Проблемам функціонування та розвитку страхового ринку України присвячені праці таких вітчизняних вчених як: Волкова В. В., Зоря О. П., Гайдаржийська О. М., Горобінська I. В., Сташкевич Н. М., Матвєєв В. В., Козьменко О. В. та інші. Проте, 
постає необхідність у систематизації негативних факторів впливу на розвиток страхового ринку та засобів їх усунення.

Цілі статті: розкрити сутність поняття страховий ринок; визначити особливості його функціонування; обгрунтувати основні чинники негативного впливу на розвиток страхового ринку та шляхи їх подолання.

Виклад основного матеріалу дослідження з повним обгрунтуванням отриманих наукових результатів. Трактуванню сутності страхового ринку присвячено велику кількість публікацій. Одні вбачають в сутності страхового ринку захисну складову, трактуючи його як середовище захисту майнових інтересів суб'єктів; інші трактують його як систему мобілізації тимчасово вільних коштів страхувальників, або як місце купівлі-продажу страхових продуктів.

На нашу думку, страховий ринок являє собою усю сукупність фінансово-економічних відносин 3 приводу обігу страхових послуг, які забезпечують страховий захист фізичних та юридичних осіб, а також виступає у ролі акумулятора вільних грошових ресурсів, перерозподіляючи їх через фінансові механізми у реальний сектор економіки.

Завдяки якісному функціонуванню страхового ринку зумовлюється підвищення соціального захисту населення та суб'єктів господарювання, зменшення навантаження на державний бюджет в разі настання стихійних лих. Останнє сприяє підвищенню зацікавленості держави в ефективному розвитку ринку. Свідченням цього було прийняття та ухвалення низки програм розвитку страхового ринку. Перелік поставлених та виконаних завдань за даними програмами подано в табл. 1 .

Таблиця 1

Еволюція розвитку страхового ринку України, крізь призму урядових заходів ${ }^{*}$

\begin{tabular}{|c|c|}
\hline \multicolumn{1}{|c|}{ Заплановані заходи } & \multicolumn{1}{c|}{ Реалізовані заходи } \\
\hline \multicolumn{1}{|c|}{1} & \multicolumn{1}{|c|}{2} \\
\hline \multicolumn{2}{|c|}{ Програма розвитку страхового ринку України на 1998-2001 pp. } \\
\hline - удосконалення нормативної бази; & доповнено та удосконалено Закон \\
- розвиток інфраструктури страхо- & України «Про страхування»; \\
вого ринку; & - прийнято Закон України «Про \\
\hline
\end{tabular}


Продовження табл. 1

\begin{tabular}{|c|c|}
\hline 1 & 2 \\
\hline $\begin{array}{l}\text { - підвищення платоспроможності } \\
\text { страховиків; } \\
\text { - покращення процедури оподатку- } \\
\text { вання страхових компаній. }\end{array}$ & $\begin{array}{l}\text { обов’язкове державне соціальне страху } \\
\text { вання на випадок безробіття»; } \\
\text { - прийнято постанову Уряду щодо } \\
\text { діяльності аварійних комісарів. }\end{array}$ \\
\hline \multicolumn{2}{|c|}{ 2. Програма розвитку страхового ринку України на 2001-2004рр. } \\
\hline $\begin{array}{l}\text { - підвищення рівня державного } \\
\text { нагляду за страховою діяльністю; } \\
\text { - відновлення довіри до страхово- } \\
\text { го захисту; } \\
\text { - підвищення фінансової стійкос- } \\
\text { ті страхових компаній; } \\
\text { - кадрове забезпечення страхови- } \\
\text { ків. }\end{array}$ & $\begin{array}{l}\text { - розпорядженням Держфінпослуг } \\
\text { затверджено Положення про навчання, } \\
\text { перепідготовку, підвищення кваліфіка- } \\
\text { ції та складання екзаменів особами, які } \\
\text { провадять діяльність на ринках фінан- } \\
\text { сових послуг; } \\
\text { - законопроектна діяльність у сфері } \\
\text { медичного страхування, страхування } \\
\text { життя, недержавного пенсійного стра- } \\
\text { хування. }\end{array}$ \\
\hline
\end{tabular}

3. Концепція розвитку страхового ринку України до 2010 р.

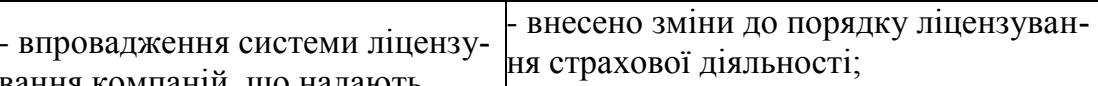
вання компаній, що надають послуги перестрахування;

- зменшення кількості видів обов'язкового страхування; - розвиток системи страхування життя.

- узаконено діяльність страхових та перестрахових брокерів;

- визначено вимоги та установлено порядок оприлюднення інформації про результати діяльності страховиків і страхових посередників.

4. Стратегія розвитку страхового ринку України в 2011-2020 pp.

\begin{tabular}{l|l|}
\hline & $-2011-2014$ рр. - розробка закону про \\
- покращення стану страхового & оздоровлення та подолання наслідків \\
ринку та подолання наслідків & фінансової кризи; \\
кризи; & $-2014-2017$ рр. - впровадження прийн- \\
- побудова прозорого та ефектив- & ятих на першому етапі актів законодав- \\
ного нагляду за страховим рин- & ства; \\
ком; & -32017 р. - Нацкомфінслуг введено \\
впровадження реального захистукількісні обмеження щодо інвестування \\
прав споживачів. & активів страховиків за рівнем ризико- \\
& вості. \\
\hline
\end{tabular}

*складено авторами на основі джерел [2]-[5] 
Отже, протягом останніх років, реалізуючи програми державного регулювання, уряд приділяв значну увагу розвитку страхового ринку. Однак тенденції розвитку страхування постійно змінюються та вдосконалюються, що вимагає від держави належного реагування.

Український страховий ринок стрімко розвивається, тому для вирішення наявних проблем, важливо більш детально розглянути основні показники його функціонування.

За даними Нацкомфінпослуг, страховий ринок має найбільший рівень капіталізації порівняно з іншими небанківськими фінансовими ринками. Станом на 31.12.2018 р. кількість зареєстрованих страховиків становила 281, у тому числі страхові компанії «life» - 30 компаній. Протягом останніх років кількість страхових компаній в Україні поступово зменшується, зокрема протягом 2014 року зменшилась на 25 компаній, у 2015 році - на 21, у 2016 році на 51, у 2017 році - на 16 та у 2018 році - на 13. В основному стрімко скорочувалася кількість страхових компаній зі страхування життя, адже ще на початку 2014 р. їх було вдвічі більше (62 компанii) $[1]$.

Проведемо більш детальний аналіз результатів функціонування страхового ринку. На рис. 1 подано динаміку чистих страхових премій та чистих страхових виплат.

Згідно даних, зображених на рисунку, величина чистих страхових премій протягом 2014-2018 рр. поступово зростає. Зокрема станом на 2014 р. величина чистих страхових премій становила 18592,8 млн. грн., у 2015 р. чисті страхові премії зросли на 3762,1 млн. грн. (20,2 \%), у 2016 р. - на 4 109,0 млн. грн. (18,4 \%), у 2017 p. - на 2 030,5 млн. грн. (7,7 \%), у 2018 р. - на 5 929,9 млн. грн. $(20,8$ \%). Загалом збільшення страхових премій відбулося за рахунок зростання таких видів страхування як: страхування майна, медичне страхування, страхування відповідальності перед третіми особами, автострахування, авіаційне страхування, страхування медичних витрат, страхування від нещасних випадків. 


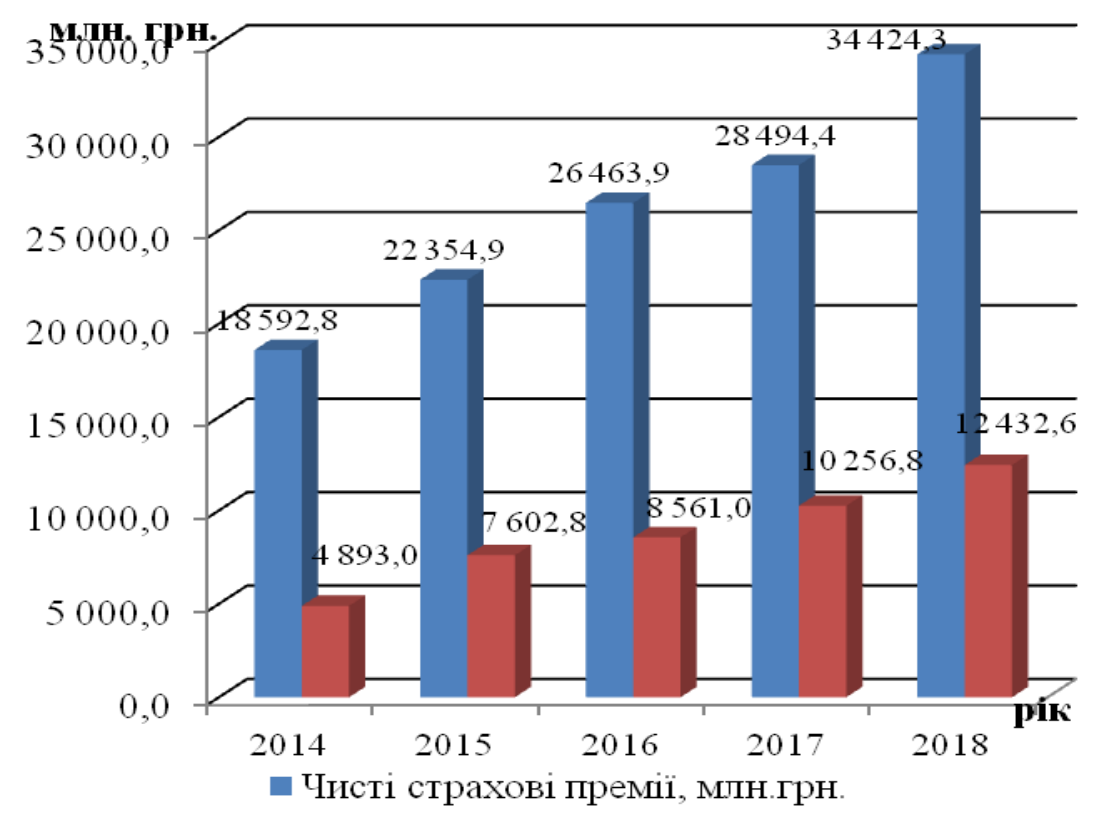

Рис. 1. Динаміка чистих страхових премій та чистих страхових виплат за усіма страховиками протягом 2014-2018 pp.

Чисті страхові виплати протягом 2014-2018 рр. мають тенденцію до зростання. Станом на 2014 р. величина чистих страхових виплат становить 4 893,0 млн. грн., проте вже протягом 2015 р. їх велична зросла на 55,4 \% (2 709,8 млн. грн.), у 2016 р. - 12,6 \% (958,2 млн. грн.), у 2017 р. - на 19,8 \% (1 695,8 млн. грн.), у 2018 р. - на 21,2 \% (2 175,8 млн. грн.). Загалом збільшились страхові виплати 3 таких видів страхування: автострахування, страхування майна, страхування життя, медичне страхування.

Хоча проаналізовані показники свідчать про поступовий динамічних розвиток страхового ринку, однак вирішення потребують безліч соціальних, правових та економічних проблем. У табл. 2 узагальнено основні недоліки в ефективному розвитку страхового ринку та шляхи їх вирішення. 
"Економічні науки". - Серія "Облік і фінанси". - Випуск 16 (61). - 2019.

Таблиця 2

Основні чинники негативного впливу на страховий ринок та шляхи їх усунення*

\begin{tabular}{|c|c|}
\hline $\begin{array}{c}\text { Фактори впливу на розвиток стра- } \\
\text { хового ринку }\end{array}$ & $\begin{array}{c}\text { Заходи стабілізації ситуації на стра- } \\
\text { ховому ринку }\end{array}$ \\
\hline $\begin{array}{l}\text { військові дії на сході країни, } \\
\text { внаслідок яких відбувається скоро- } \\
\text { чення страхових премій; } \\
\text { - зниження попиту на страхові } \\
\text { продукти через низький рівень } \\
\text { платоспроможності населення; } \\
\text { - низький рівень довіри до вітчиз- } \\
\text { няних страховиків; } \\
\text { - недосконала нормативно-правова } \\
\text { база; } \\
\text { - відсутність чіткої стратегії розви- } \\
\text { тку страхового ринку; } \\
\text {-обтяжуюча система оподаткуван- } \\
\text { ня; } \\
\text { - слабкий розвиток фондового } \\
\text { ринку, що стримує інвестиційну } \\
\text { діяльність }\end{array}$ & $\begin{array}{l}\text { - впровадження міжнародних станда- } \\
\text { ртів ведення страхової діяльності; } \\
\text { - введення диференційованого опода- } \\
\text { ткування прибутків страховиків; } \\
\text { - мінімізація зловживань державною } \\
\text { владою при контролі; } \\
\text { - інформування населення через 3МІ } \\
\text { про стан страхового ринку; } \\
\text { - розробка нових нормативно- } \\
\text { правових актів та постанов; } \\
\text { - впровадження механізмів, які сти- } \\
\text { мулюватимуть інвестування страхо- } \\
\text { вих резервів у національну економіку }\end{array}$ \\
\hline
\end{tabular}

*складено авторами на основі джерел [6], [7]

Таким чином, становлення та розвиток страхового ринку відбувався за відсутності дієвої нормативно-законодавчої бази, за відсутності ефективного державного нагляду за діяльністю страховиків та в умовах економічної кризи. Тому, неможливо впевнено сказати, на якій стадії розвитку перебуває страховий ринок України, адже вирішення потребують безліч проблем в страховій діяльності.

Безліч негативних факторів не дають страховому ринку повноцінно розвиватися, що змушує іноземних інвесторів до пошуку інших, більш привабливих варіантів вкладення коштів у сферу страхування.

Отже, для подолання проблем та ефективного реформування страхового ринку необхідно здійснити наступні заходи:

- стимулювати страховиків до отримання міжнародних рейтингів фінансової надійності; 
"Економічні науки". - Серія "Облік і фінанси". - Випуск 16 (61). - 2019.

- визначити єдину та ефективну стратегію розвитку страхового ринку України;

- ввести світові стандарти ведення страхової діяльності;

- посилити контроль за страховиками з боку державних органів влади щодо забезпечення платоспроможності та фінансової стійкості;

- створити якісну систему підготовки висококваліфікованих кадрів для страхової галузі;

- посилити роботу зі створення та впровадження додаткових нормативно-правових актів.

Висновки. Отже, страховий ринок України поступово розвивається, проте існує велика кількість факторів, які негативно впливають на діяльність страхового сектора. Для подолання кризових явищ необхідно негайно впроваджувати заходи стабілізації ситуації на страховому ринку. Однак практичних навичок для вирішення наявних проблем у страховій галузі країна не має, тому вважаємо за доцільне розглянути стан страхових ринків інших економічно розвинених країн світу з метою впровадження їх досвіду в Україні.

1. Офіційний сайт Національної комісії, що здійснює державне регулювання у сфері ринків фінансових послуг: Огляд страхового ринку. URL: https://www.nfp.gov.ua (дата звернення: 02.11.2019).

2. Про затвердження Програми розвитку страхового ринку України на 1998-2001 роки URL: https://uazakon.com/documents/ date_aa/pg_icnhos. (дата звернення: 07.10.2019).

3. Про затвердження Програми розвитку страхового ринку України на 2001-2004 роки. URL: https://zakon.rada.gov.ua/laws/main/98-2001-п (дата звернення: 08.10.2019).

4. Про схвалення Концепції розвитку страхового ринку України до 2010 року URL: https://zakon.rada.gov.ua/laws/main/369-2005-p (дата звернення: 08.10.2019).

5. Стратегія розвитку страхового ринку України на 2012-2021 роки. URL: http://ufu.org.ua/ua/about/activities/strategic_initiatives/5257 (дата звернення: 10.10.2019).

6. Матвєєв В.В., Гайдаржийська О.М., Отрошко В.П. Страховий ринок України: сучасний стан та перспективи розвитку. Молодий вчений. 2018. №2(2). С. 727731.

7. Городніченко Ю. В. Тенденції та перспективи розвитку страхового ринку України. Економіка і суспільство. 2017. №10. С. 569-573. 